NASA/TM-2009-215612

AIAA-2008-4812

\title{
NASA's Evolutionary Xenon Thruster (NEXT) Component Verification Testing
}

Daniel A. Herman

ASRC Aerospace Corporation, Cleveland, Ohio

Luis R. Pinero

Glenn Research Center, Cleveland, Ohio

James S. Sovey

Alphaport, Inc., Cleveland, Ohio 


\section{NASA STI Program . . . in Profile}

Since its founding, NASA has been dedicated to the advancement of aeronautics and space science. The NASA Scientific and Technical Information (STI) program plays a key part in helping NASA maintain this important role.

The NASA STI Program operates under the auspices of the Agency Chief Information Officer. It collects, organizes, provides for archiving, and disseminates NASA's STI. The NASA STI program provides access to the NASA Aeronautics and Space Database and its public interface, the NASA Technical Reports Server, thus providing one of the largest collections of aeronautical and space science STI in the world. Results are published in both non-NASA channels and by NASA in the NASA STI Report Series, which includes the following report types:

- TECHNICAL PUBLICATION. Reports of completed research or a major significant phase of research that present the results of NASA programs and include extensive data or theoretical analysis. Includes compilations of significant scientific and technical data and information deemed to be of continuing reference value. NASA counterpart of peer-reviewed formal professional papers but has less stringent limitations on manuscript length and extent of graphic presentations.

- TECHNICAL MEMORANDUM. Scientific and technical findings that are preliminary or of specialized interest, e.g., quick release reports, working papers, and bibliographies that contain minimal annotation. Does not contain extensive analysis.

- CONTRACTOR REPORT. Scientific and technical findings by NASA-sponsored contractors and grantees.

- CONFERENCE PUBLICATION. Collected papers from scientific and technical conferences, symposia, seminars, or other meetings sponsored or cosponsored by NASA.

- SPECIAL PUBLICATION. Scientific, technical, or historical information from NASA programs, projects, and missions, often concerned with subjects having substantial public interest.

- TECHNICAL TRANSLATION. Englishlanguage translations of foreign scientific and technical material pertinent to NASA's mission.

Specialized services also include creating custom thesauri, building customized databases, organizing and publishing research results.

For more information about the NASA STI program, see the following:

- Access the NASA STI program home page at http://www.sti.nasa.gov

- E-mail your question via the Internet to help@ sti.nasa.gov

- Fax your question to the NASA STI Help Desk at 301-621-0134

- Telephone the NASA STI Help Desk at $301-621-0390$

- Write to: NASA Center for AeroSpace Information (CASI) 7115 Standard Drive Hanover, MD 21076-1320 


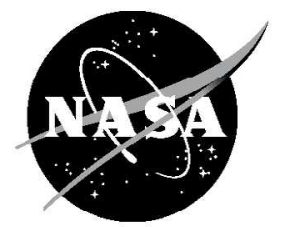

\section{NASA's Evolutionary Xenon Thruster (NEXT) Component Verification Testing}

Daniel A. Herman

ASRC Aerospace Corporation, Cleveland, Ohio

\section{Luis R. Pinero}

Glenn Research Center, Cleveland, Ohio

James S. Sovey

Alphaport, Inc., Cleveland, Ohio

Prepared for the

44th Joint Propulsion Conference and Exhibit

cosponsored by the AIAA, ASME, SAE, and ASEE

Hartford, Connecticut, July 21-23, 2008

National Aeronautics and

Space Administration

Glenn Research Center

Cleveland, Ohio 44135 
Level of Review: This material has been technically reviewed by technical management.

Available from

NASA Center for Aerospace Information

7115 Standard Drive

Hanover, MD 21076-1320
National Technical Information Service 5285 Port Royal Road Springfield, VA 22161

Available electronically at http://gltrs.grc.nasa.gov 


\title{
NASA's Evolutionary Xenon Thruster (NEXT) Component Verification Testing
}

\author{
Daniel A. Herman \\ ASRC Aerospace Corporation \\ Cleveland, Ohio 44135 \\ Luis R. Pinero \\ National Aeronautics and Space Administration \\ Glenn Research Center \\ Cleveland, Ohio 44135 \\ James S. Sovey \\ Alphaport, Inc. \\ Cleveland, Ohio 44135
}

\begin{abstract}
Component testing is a critical facet of the comprehensive thruster life validation strategy devised by the NASA's Evolutionary Xenon Thruster (NEXT) program. Component testing to-date has consisted of long-duration high voltage propellant isolator and high-cycle heater life validation testing. The high voltage propellant isolator, a heritage design, will be operated under different environmental condition in the NEXT ion thruster requiring verification testing. The life test of two NEXT isolators was initiated with comparable voltage and pressure conditions with a higher temperature than measured for the NEXT prototype-model thruster. To date the NEXT isolators have accumulated $18,300 \mathrm{~h}$ of operation. Measurements indicate a negligible increase in leakage current over the testing duration to date. NEXT $1 / 2$ in. heaters, whose manufacturing and control processes have heritage, were selected for verification testing based upon the change in physical dimensions resulting in a higher operating voltage as well as potential differences in thermal environment. The heater fabrication processes, developed for the International Space Station (ISS) plasma contactor hollow cathode assembly, were utilized with modification of heater dimensions to accommodate a larger cathode. Cyclic testing of five $1 / 2$ in. diameter heaters was initiated to validate these modified fabrication processes while retaining high reliability heaters. To date two of the heaters have been cycled to 10,000 cycles and suspended to preserve hardware. Three of the heaters have been cycled to failure giving a $B_{10}$ life of 12,615 cycles, approximately 6,000 more cycles than the established qualification $B_{10}$ life of the ISS plasma contactor heaters.
\end{abstract}

\section{Nomenclature}

$B_{1} \quad$ statistical number of cycles in which 1 percent of components are expected to fail with 90 percent confidence

$B_{10} \quad$ statistical number of cycles in which 10 percent of components are expected to fail with 90 percent confidence

BOL beginning-of-life

DAC data acquisition and control system

DCIU digital control interface unit

DS1 Deep Space 1

EM engineering model

$F(t) \quad$ fraction of units failing

GRC NASA Glenn Research Center

HiPEP High Power Electric Propulsion 


$\begin{array}{ll}\text { HVPI } & \text { high voltage propellant isolator } \\ \text { IPS } & \text { ion propulsion system } \\ \text { ISS } & \text { International Space Station } \\ \text { LDT } & \text { Long-Duration Test } \\ \text { NEXT } & \text { NASA's Evolutionary Xenon Thruster } \\ \text { NSTAR } & \text { NASA Solar Electric Propulsion Technology Applications Readiness } \\ \text { PM } & \text { Prototype Model } \\ \text { PMS } & \text { propellant management system } \\ \text { PPU } & \text { power processing unit } \\ \text { SEP } & \text { Solar Electric Propulsion } \\ \text { SOA } & \text { state-of-the-art } \\ t & \text { cycles to failure } \\ t_{0} & \text { origin of distribution } \\ \text { VF-62 } & \text { Vacuum Facility } 62 \\ \text { Xe } & \text { xenon } \\ \beta & \text { slope or shape parameter } \\ \eta & \text { characteristic life or scale parameter }\end{array}$

\section{Introduction}

NASA's Evolutionary Xenon Thruster (NEXT), led by the NASA Glenn Research Center (GRC), is being developed to meet NASA's future mission propulsion needs for a more-advanced, higher-power ion propulsion system (IPS) at low total development cost. The success of the NASA Solar Electric Propulsion Technology Applications Readiness (NSTAR) ion propulsion system on Deep Space 1 (DS1) secured the future for ion propulsion technology for future NASA missions (Refs 1 to 3 ). In-space propulsion technology analyses conducted at NASA identified the need for a higher-power, higher total throughput capability ion propulsion system beyond the $2.3 \mathrm{~kW}$ NSTAR ion thruster targeted for robotic exploration of the outer planets. The NEXT project is tasked with development of the next-generation ion propulsion system to meet NASA's present and future propulsion needs. The NEXT Solar Electric Propulsion (SEP) system design enhances and enables Discovery, New Frontiers, and other exploration mission classes (Refs 4 and 5). Several of the Discovery-class mission studies demonstrated NEXT outperforming the state-of-the-art (SOA) NSTAR, yielding higher net payload mass with fewer thrusters (Ref. 6). Several of the New Frontiers and Flagship-class mission studies showed that NEXT was either mission-enhancing or mission-enabling (Refs. 4 and 7). NEXT technology is applicable to a wide range of NASA solar system exploration missions, as well as earth-space commercial and other missions of national interest. NEXT affords larger delivered payloads and smaller launch vehicle size than chemical propulsion for Discovery, New Frontiers, Mars Exploration, and Flagship outer-planet exploration missions.

The NEXT system consists of a high-performance, $7 \mathrm{~kW}$ ion thruster; a high-efficiency, modular, $7 \mathrm{~kW}$ power processing unit (PPU) ${ }^{*}$ with an efficiency and a specific power greater the NSTAR PPU; a highly-flexible, advanced Xe propellant management system (PMS) ${ }^{\dagger}$ that utilizes proportional valves and thermal throttles to reduce mass and volume; a lightweight engine gimbal; ${ }^{\ddagger}$ and key elements of a digital control interface unit (DCIU) ${ }^{\dagger}$ including software algorithms (Refs. 8 to 14). The NEXT thruster and component technologies demonstrate a significant advancement in technology beyond SOA NSTAR thruster systems. NEXT performance exceeds single or multiple NSTAR thrusters over most of the thruster input power range. The wet propulsion system mass has been reduced by higher-efficiency,

\footnotetext{
*Power Processing Unit development led by L3 Comm ETI, Torrance, California.

†Propellant Management System and DCIU simulator development led by Aerojet, Redmond, Washington.

${ }^{\ddagger}$ Gimbal development led by the Jet Propulsion Laboratory and Swales Aerospace.
} 
higher-specific impulse, and lower specific mass. With a predicted throughput capability more than double that of NSTAR, fewer NEXT thrusters are required compared NSTAR.

Validation of the NEXT thruster service life capability is being addressed via a comprehensive service life validation scheme utilizing a combination of test and analyses. A NEXT service life assessment was conducted at GRC employing several models to evaluate all known failure modes incorporating the results of the NEXT 2,000 h wear test conducted on an engineering model (EM) NEXT ion thruster at $6.9 \mathrm{~kW}$ input power. The assessment predicts the earliest failure occurring sometime after $750 \mathrm{~kg}$ of Xe throughput, well beyond the mission-derived propellant throughput requirement of $300 \mathrm{~kg}$ (Ref. 15). To verify the NEXT thruster service life model and qualify the NEXT thruster, the NEXT Long-Duration Test (LDT) was initiated. To date the NEXT LDT has demonstrated 17,000 h of operation processing $348 \mathrm{~kg}$ of Xe and demonstrating $13.0 \times 10^{6} \mathrm{~N} \cdot \mathrm{s}$ (Ref. 16). The goal of the NEXT LDT is to verify by direct test that the thruster service life capability predicted is accurate and achievable. This verification by test is a costly, yet indisputable method of thruster service life validation.

Complementary sets of NEXT component verification activities are ongoing or are planned to augment the NEXT LDT in support of validating the NEXT thruster service life assessment. A life test of two high voltage propellant isolators (HVPIs) is ongoing. The HVPIs provide electrical isolation for the Xe feed system from the discharge anode and cathode, which operate at high voltages. In the NEXT ion propulsion system, these potentials can reach as high as $1800 \mathrm{~V}$ from ground. The HVPIs were selected for validation even though they are based upon a heritage design because they sustained enough design changes and operate in a slightly different environment (Refs. 17 to 19). Factors leading to the decision of component validation include: NEXT HVPI design changed to accommodate higher operating voltages, NEXT HVPI hardware procured from a different vendor, and to verify NEXT HVPIs can handle NEXT operating pressures and temperature requirements. Two prototype-model propellant isolators, nearly identical to the design of the NEXT LDT HVPIs but fabricated from a different vender, are under-going a life test under simulated environmental conditions of voltage, pressure, and temperature. The temperature for the HVPI testing was initially set at the anticipated temperature for the NEXT Prototype-Model (PM) thruster operating in the harshest environment. Subsequent testing of the NEXT PM thruster revealed better thermal management than accounted for leading to reduced operating temperatures. The HVPI testing was continued at the elevated temperature. The primary objectives of the HVPI testing are to ensure that the design has sufficient voltage and thermal margin, identify unexpected life-limiting phenomena, characterize the HVPI performance over time, and qualify the NEXT HVPI for full power operation of a NEXT ion engine for its life requirement. The test will continue for $28,000 \mathrm{~h}$ or until the leakage current on the propellant isolators exceeds $100 \mu \mathrm{A}$. The upper bound on acceptable leakage current is extremely conservative and was chosen to be the same as the requirement for the NSTAR HVPIs (Ref. 18).

Cathode heaters, developed for the International Space Station (ISS) plasma contactor, are used to raise the low-work-function emitter temperature inside the hollow cathodes to the level at which thermionic emission occurs during the cathode ignition process. The NEXT neutralizer and discharge chamber hollow cathodes use sheathed helical heaters coiled on cathode tubes of $1 / 4$ and $1 / 2$ in. diameters, respectively. The NEXT neutralizer $1 / 4$ in. heaters are identical in materials, fabrication techniques, and dimensions to the ISS heaters permitting verification by similarity (Ref. 20). The $1 / 2 \mathrm{in}$. heaters are different in dimensions and operating voltages requiring validation though the material and fabrication techniques have heritage from the ISS plasma contactor. Half inch GRC-manufactured heaters have completed cyclic life testing to evaluate reliability and validate the heater manufacturing and performance. Five $1 / 2$ in. heaters have completed cyclic testing with two units suspended after 10,000 cycles to preserve hardware, while three units were cycled to failure. An encompassing GRCmanufactured heater qualification program has begun with these cyclic heater tests offering manufacturing verification.

This paper documents the test setups and results obtained to date for the HVPI and $1 / 2$ in. heater tests. Additional component testing such as thin-film adhesion to discharge chamber wire mesh and cathode ignition testing are underway or are planned. 


\section{HVPI Testing}

The NEXT HVPI design concept is based on the NSTAR HVPI that was successfully tested at the component and thruster level for 16,000 and $30,000 \mathrm{~h}$, respectively (Refs. 18 and 21). The NEXT HVPIs provide electrical isolation of the gas feed system at ground potential from the ion engine hollow cathode and discharge chamber, which can be at a potential of $1800 \mathrm{~V}$ above ground. Additional information on the HVPI initial tests can be found in Reference 22. The life validation test of two HVPIs was started on January 5, 2006. The results of the HVPI testing to date are included in the following section.

\section{High-Voltage Propellant Isolators}

The NEXT HVPIs provide electrical isolation for the Xe feed system, at ground potential, from the ion engine hollow cathode and discharge chamber, which can be at a potential of $1800 \mathrm{~V}$ above ground. The NEXT isolators based on the NSTAR design, are made of nickel-alloy housing flanges, an alumina housing, and backup alumina rings (Ref. 13). The braze is oxygen free, high conductivity copper. The HVPI has shields to prevent line-of-sight deposition of sputtered efflux or external contaminants. Shields are used because surface coatings on the HVPI alumina housing can cause unwanted current leakage from high voltage to ground. A photograph of the HVPIs is shown in Figure 1. In addition to having a much higher voltage capability compared to the NSTAR HVPI, the NEXT HVPI design has a smaller radial envelope than the NSTAR unit. The smaller diameter reduces mass and mitigates risk associated with vibration environments.

\section{HVPI Test Setup}

The HVPI test is being performed in GRC's Vacuum Facility 62 (VF-62), which is a cryogenically pumped vacuum chamber $30 \mathrm{~cm}$ in diameter and $76 \mathrm{~cm}$ long. An oil-free roughing pump is used in conjunction with a cryogenic pump, which has a pumping speed of $2100 \mathrm{l} / \mathrm{s}$. The typical operating pressure is $0.1 \mathrm{mPa}$. The pressure in the vacuum chamber is very low because the Xe flow through the HVPIs does not exhaust into the chamber but is plumbed through the chamber flange to an auxiliary scroll pump that maintains a pressure of about $38 \mathrm{~Pa}$ at the HVPI exit. Two isolators are heated inside a radiation shield by four tungsten-halogen lamps. A laboratory power supply provides high voltage across the isolators while leakage currents are measured by an electrometer with capability to measure less than a nanoampere (Ref. 2). More detailed information on the test setup can be found in Reference 22 .

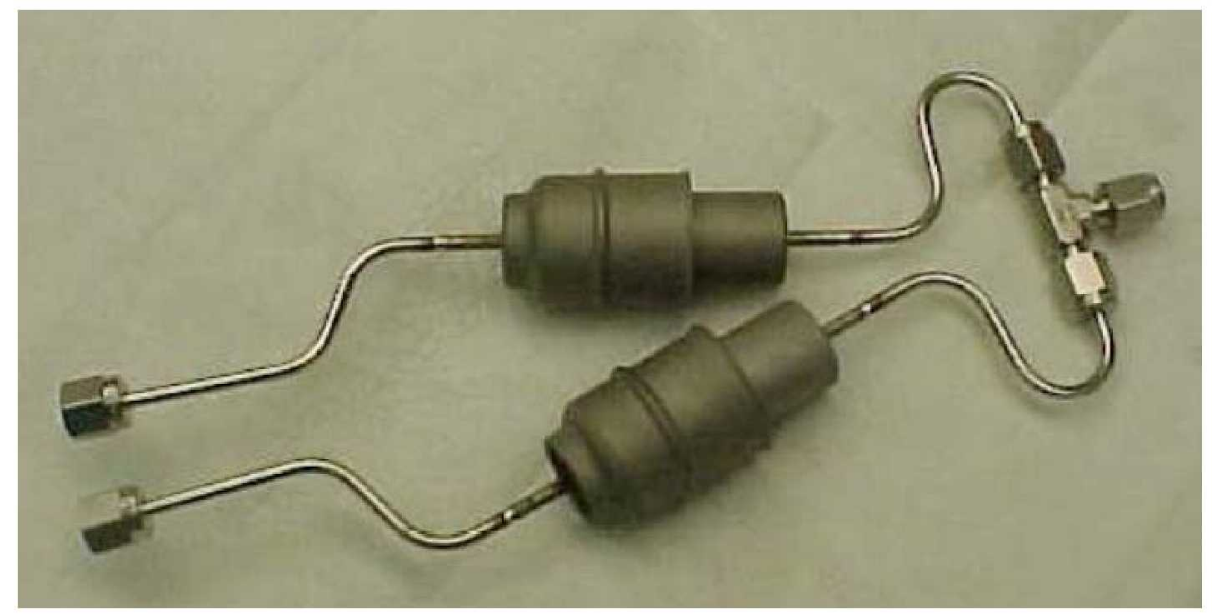

Figure 1.-NEXT HVPIs with propellant tubing prior to installation. 


\section{Operating Parameters and Procedure}

It was decided that the HVPI component test be conducted similar voltage, temperature and pressure conditions as it will experience with a thruster. A voltage of $2300 \mathrm{~V}$ was selected to have at least $500 \mathrm{~V}$ over the maximum voltage set point. A temperature of $260^{\circ} \mathrm{C}$ was selected because that is estimated to be about $40^{\circ} \mathrm{C}$ higher than isolator temperatures for the NEXT EM thruster operated at full power, without an adiabatic enclosure and without solar simulation. Preliminary thermal model results predict that the anode of the NEXT Prototype Model (PM) thruster discharge chamber will have a temperature about $75^{\circ} \mathrm{C}$ cooler than the EM thruster when operated at full-power (Ref. 23). Given these temperature indications, it is estimated that the HVPI component test temperature of $260^{\circ} \mathrm{C}$ would provide about $65^{\circ} \mathrm{C}$ margin for the PM thruster in the worst-case environment that included three operating thrusters in an adiabatic enclosure, at $0.85 \mathrm{AU}$, and $38^{\circ}$ off-axis sun angle (Ref. 23). Finally, a pressure of approximately $2.7 \mathrm{kPa}$ downstream of the isolators is being used (Ref. 22). The life validation test will be conducted for a period of no less than $28,000 \mathrm{~h}$, which is the qualification-test requirement for the NEXT thruster (Refs. 15 and 24). Additional information on the definition of the HVPI testing parameters, pretest preparations, and functional tests can be found in Reference 22 .

\section{HVPI Results}

During the life validation test, the temperature of the HVPIs is maintained at $260 \pm 5^{\circ} \mathrm{C}$, voltage is set to $2300 \mathrm{~V}$, and the downstream pressure is maintained at $2.7 \pm 0.3 \mathrm{kPa}$. Testing is initiated only if the facility pressure is below $270 \mu \mathrm{Pa}$. As of June 2008 , more than $18,300 \mathrm{~h}$ of operation have been accumulated. Test down time has been minimal resulting in a test duty cycle of about 87 percent. The background pressure in the test facility during the test was typically $130 \mu \mathrm{Pa}$. Figure 2 shows the leakage current through both isolators versus time. At the beginning of the test the leakage current was less than $0.1 \mathrm{nA}$ and very slowly increased with time. Between 7500 and $9500 \mathrm{~h}$, the current measurements became erratic. This was due to a short circuit from one of the radiant heater electrical sockets to the vacuum facility that caused ground currents that coupled into the isolator circuit affecting the leakage current measurement. The heater socket was replaced and the test resumed. Leakage current measurements returned to the levels they were before the incident and seem to continue its previous trend. The leakage current is currently increasing at a rate of approximately $0.1 \mathrm{nA}$ every $2900 \mathrm{~h}$. Its value is five orders of magnitude lower than the maximum allowable leakage current requirement of $100 \mu \mathrm{A}$, and there is no threat to long-term operation.

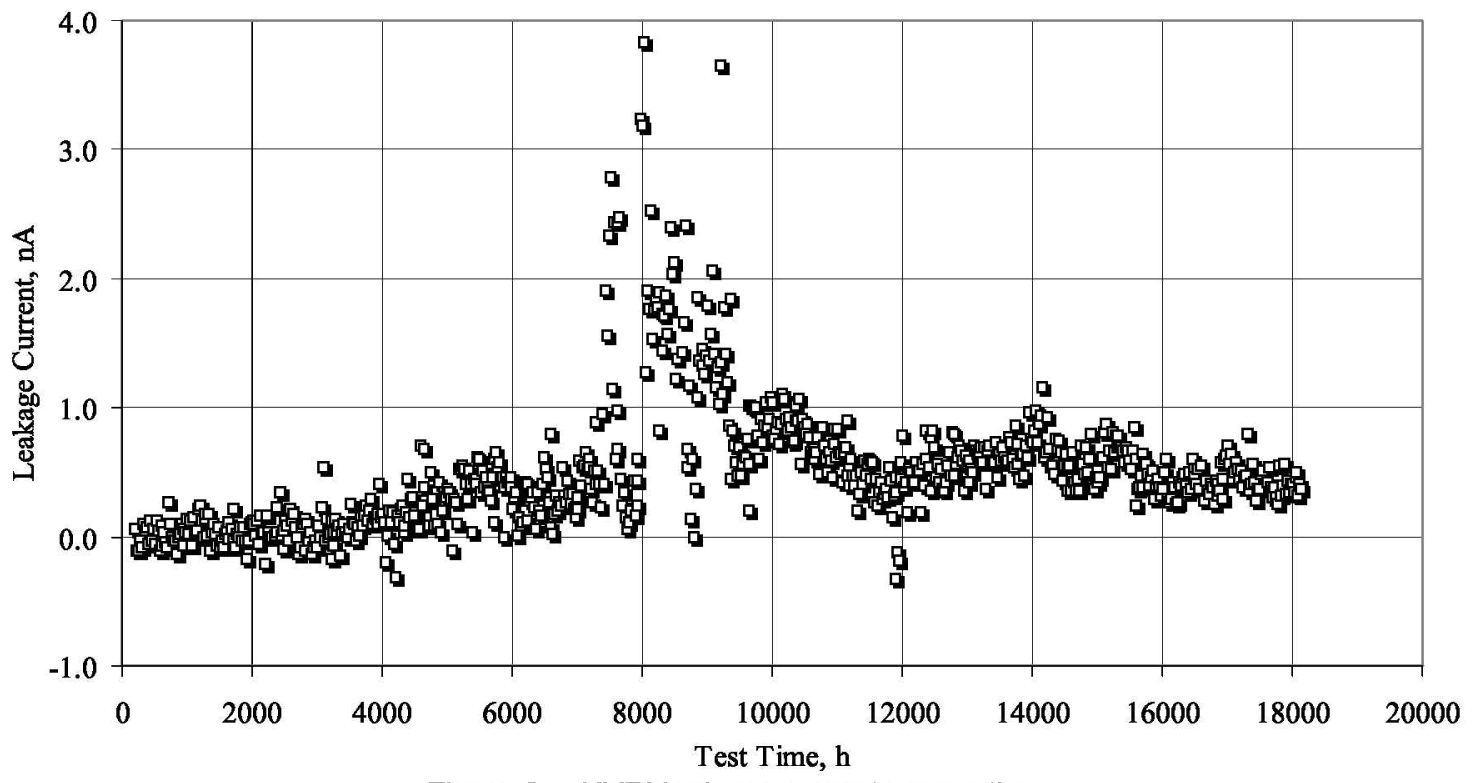

Figure 2.-HVPI leakage current versus time. 


\section{Half-Inch Heater Cyclic Testing}

The following section describes the heaters that have been tested, the test setup, the testing operating parameters and procedures, and the cyclic testing results. A comprehensive GRC-manufactured $1 / 2$ in. heater qualification program has been initiated. The cyclic heater tests results presented in this paper offer manufacturing process validation and demonstrate confidence that the $1 / 2$ in. heater design will yield the required cycle lifetimes. The target cycle lifetime is greater than the ISS $B_{10}$ lifetime of 6,679 cycles.

\section{Half-Inch Heater Test Articles}

Five different $1 / 2$ in. heaters were subjected to cyclic testing. Photographs of the test articles and summary information are given in Table 1 . Four of the heaters tested were installed in complete discharge cathode assemblies (DCAs) including the electron emitting inserts to match the thermal mass and environment. A $\frac{1}{2} \mathrm{in}$. heater coil section, previously used and removed following the NEXT $2,000 \mathrm{~h}$ wear test, was installed on a hollow cathode tube with radiation shielding, but no emitter (Refs. 25 and 26). This $1 / 2$ in. heater coil, as well as one of the DCA's, was outfitted with a thermocouple located on the cathode tube in the plane of the inside edge of the cathode orifice plate. The $1 / 2$ in. heater coil had previously operated for 40 ignitions and 8 cathode conditioning sequences during the NEXT $2,000 \mathrm{~h}$ wear test totaling $37.4 \mathrm{~h}$ of current application $(196 \mathrm{~A} \cdot \mathrm{h})$ (Ref. 25). Another heater that had been operated for significant duration is EM DCA2, which has a graphite keeper electrode and was operated during the High Power Electric Propulsion (HiPEP) 2,000 h wear test (Ref. 27).

\begin{tabular}{|l|c|c|c|l|}
\multicolumn{1}{|c|}{ TABLE 1.-HALF-INCH GRC-MANUFACTURED HEATER CYCLIC TEST RESULTS SUMMARY } \\
\hline Article & $\begin{array}{c}\text { Cycles } \\
\text { Demonstrated }\end{array}$ & Status & \multicolumn{1}{c|}{ Notes } \\
\hline 1/2 in. HTR-10 & 13,895 & $\begin{array}{c}\text { Failed } \\
\text { open-circuit }\end{array}$ & $\begin{array}{l}\text { Coil section from NEXT 2 kh } \\
\text { wear test mounted on new } \\
\text { cathode tube; No insert }\end{array}$ \\
\hline EM DCA1 & 14,257 & $\begin{array}{c}\text { Failed } \\
\text { open-circuit }\end{array}$ & Completed EM DCA \\
\hline EM DCA2 & 13,789 & $\begin{array}{c}\text { Failed } \\
\text { open-circuit }\end{array}$ & $\begin{array}{l}\text { EM DCA used in HiPEP } \\
\text { 2 kh wear test; Graphite } \\
\text { keeper (Ref. 27) }\end{array}$ \\
\hline EM DCA11 & & 10,000 & $\begin{array}{c}\text { Operational: } \\
\text { suspended } \\
\text { from test }\end{array}$ & Completed EM DCA \\
\hline
\end{tabular}

\section{Cyclic Heater Test Setup}

The DCAs and cathode tube were mounted on the heater test fixture, shown in Figure 3, which allows simultaneous testing of up to 6 heaters. Ceramic insulators at the mounting location (bottom) provide electrical and thermal isolation against conducted heat. Stainless steel radiation shields eliminate radiated heat interaction between neighboring heaters during testing. The test fixture is installed in VF-65 at GRC. This is a $91 \mathrm{~cm}$ long by $48 \mathrm{~cm}$ diameter cryogenically pumped belljar with a glass dome. The average, and typical, operating pressure of the bell jar during current application is $13.3 \mu \mathrm{Pa}$. The heater test is controlled by an automated data acquisition and control system (DAC) that 

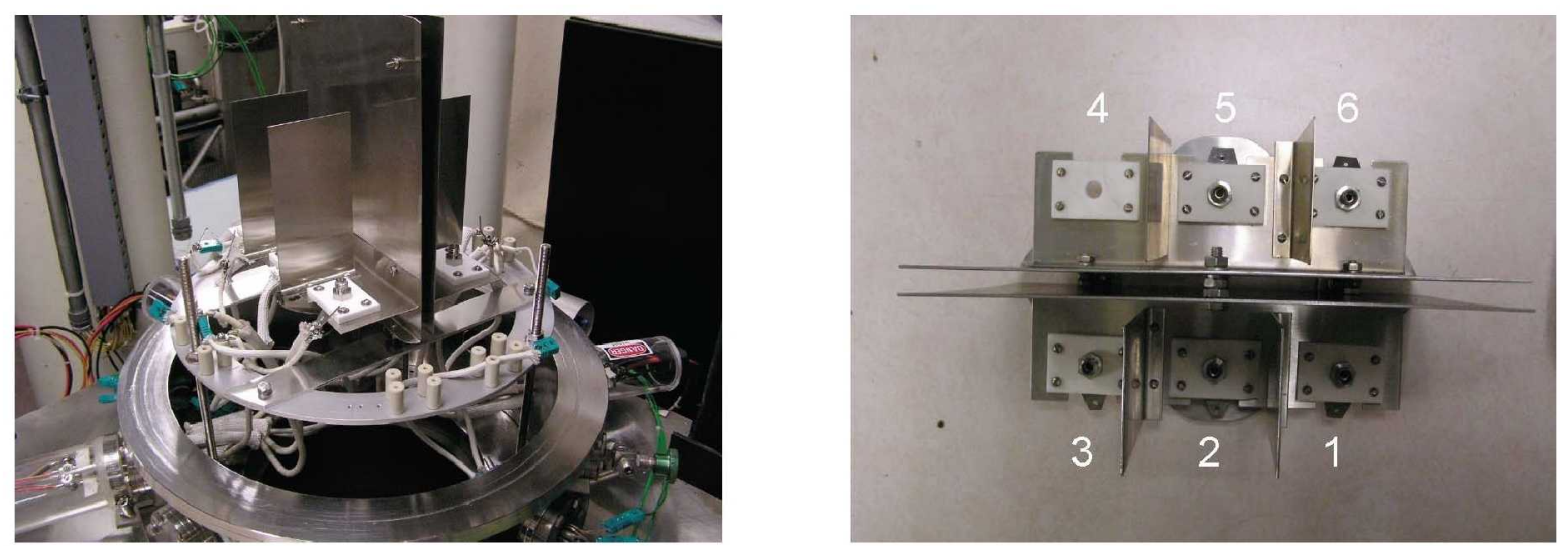

Figure 3.-Half inch heater test fixture installed in VF65 with bell jar removed (left) and top view (right).

utilizes isolated Hall effect sensors to measure currents. Voltages are measured at the vacuum feed through to reduce voltage drops. Heater temperatures for the two units are made with R-type thermocouples. Additional information on the heater test setup can be found in Reference 22.

\section{Operating Parameters and Procedure}

The test sequence includes two procedures. First, the heaters complete a conditioning procedure established during the ISS plasma contactor effort that has been used in for both NSTAR and NEXT programs to remove absorbed impurities on the hollow cathode emitter surfaces. This procedure is only used when the bell jar is exposed to elevated pressures, such as venting of the facility, and prior to cyclic heater testing. The heater cyclic testing consists of repeated cycles (on for $6 \mathrm{~min}$ and off for $4 \mathrm{~min}$ ) operating at a fixed current of $8.50 \mathrm{~A}$, which is the current used for cathode ignition. The 6 min duration is consistent with the ISS plasma contactor heater cyclic testing to establish the $B_{10}$ life for $1 / 4 \mathrm{in}$. GRCmanufactured heaters. The $6 \mathrm{~min}$ duration is also consistent with the NEXT EM hollow cathode ignition database for encompassing $>90$ percent of all discharge cathode ignition times to date. The $4 \mathrm{~min}$ off duration is consistent with ISS plasma contactor heater qualification testing. Cycles are continuously carried out with the exception of facility issues, test setup modification, and data recording breaks, which occur approximately every 1,000 cycles. The heaters, cycled until failure or suspension, are shown with 8.50 A heater current in Figure 4. The most common failure mode is an open circuit of the center conductor due to grain growth. The cyclic life test is a worst-case test subjecting the NEXT $1 / 2 \mathrm{in}$. heaters to orders of magnitude more cycles than required for deep space missions. The success criterion for the $1 / 2$ in. heater cyclic life test is heaters meet or exceed the $B_{10}$ lifetime of the ISS plasma contactor hollow cathode assembly. This is the statistical number of cycles at which 10 percent of the heaters would be expected to have failed with 90 percent confidence. The ISS $B_{10}$ life was established to be 6,679 cycles.

\section{Cyclic Heater Test Results}

Since the testing cycles are operated at set currents, the independent parameter of interest is heater voltage. Equivalently this voltage can be converted to an operating heater resistance by dividing the voltage by $8.50 \mathrm{~A}$. Observations about the voltage as a function of time during heater "on" segments as well as the end of heater "on" voltage as a function of heater cycle can give important information about the heater operations. The same is true of heater hot resistance. Note that because of its shorter length the $1 / 2$ in. heater coil section demonstrates a reduced voltage compared to the heaters inside EM DCAs. During testing additional heater section was added in series with the $1 / 2$ in. heater coil resulting in an increase in operating voltage that turns out to be comparable to the other heaters operating in DCAs. As a matter of preference, individual heater segments will be plotted as voltage versus time, while heater endof-current performance will be plotted as a resistance normalized to beginning-of-life (BOL) value versus 

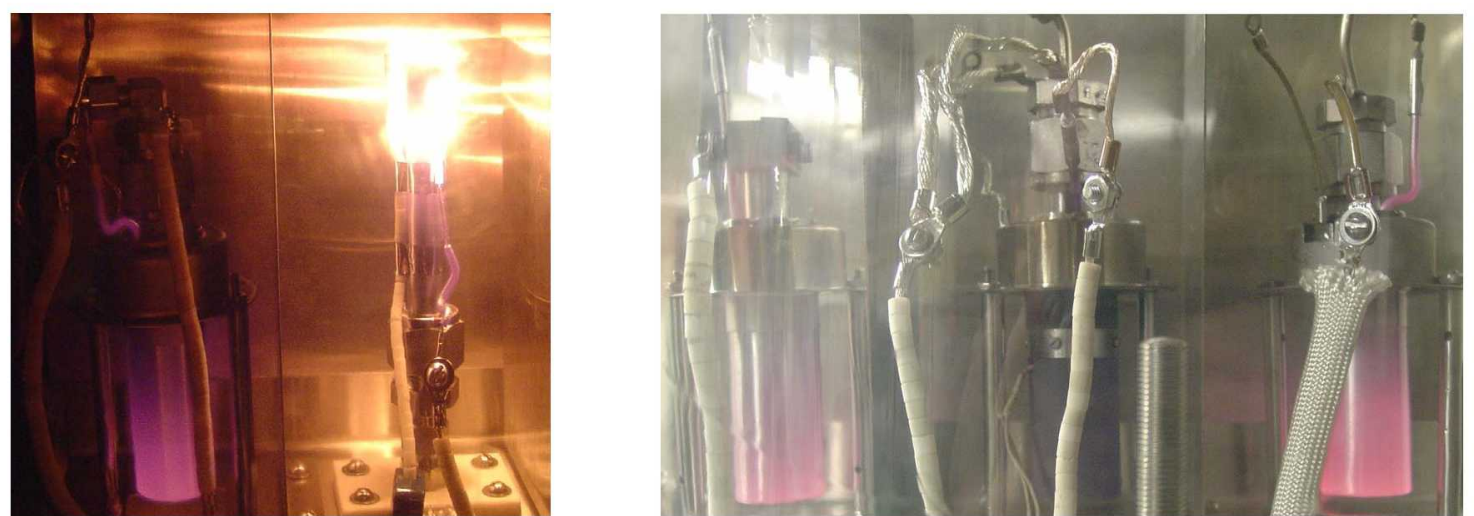

Figure 4.- Half inch heater cyclic test images from left to right: EM DCA 11, HTR-10, EM DCA 10, EM DCA2, EM DCA 1.

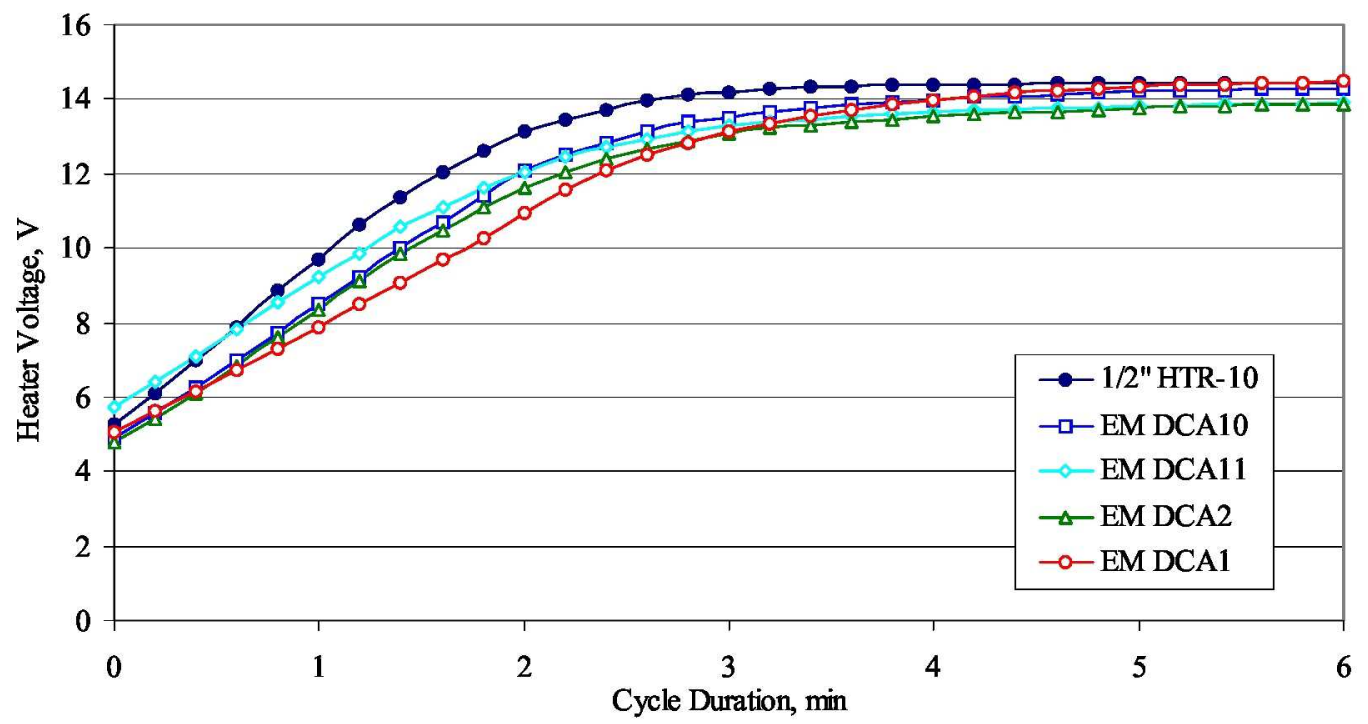

Figure 5.-Typical heater voltage versus time during 6 min "On" cycle.

cycle number. This format allows easy interpretation of typical $1 / 2$ in. heater operation during cycles and facilitates comparison of various heater performances over the test duration. A typical voltage versus time characteristic is shown for the five heaters in Figure 5. The data show comparable characteristics consistent with the rise in voltage expected from a resistive filament whose temperature is increasing with time. All heater voltages asymptote to approximately $14 \mathrm{~V}$. None of them demonstrate a voltage overshoot that can be associated with thermal-mechanical effects or leakage current path production.

The cyclic heater voltage (or equivalently resistance) values, normalized to the BOL values, are shown as a function of cycle number in Figure 6. Two $1 / 4$ in. ISS plasma contactor heaters are shown for reference. ISS HTR-038 was one of the three heaters cycled to failure during the plasma contactor qualification program that established the ISS heater $B_{10}$ life. The $1 / 2$ in. heater normalized voltage at the end of the 6 min "on" cycle all exhibit increasing trends with time as expected. Typical increases observed over the ISS plasma contactor heater life are 5 to 10 percent higher than BOL values. Three of the NEXT heaters exhibit similar magnitude increases as the ISS plasma contactor heaters. Two of the $1 / 2 \mathrm{in}$. heaters reveal increasing end-of-cycle voltage values that are 17 to 18 percent higher than beginning-oftest. Two of the $1 / 2$ in. heaters, EM DCA10 and EM DCA11, were operated for $~ 10,000$ cycles and then suspended to preserve operation of the DCAs. The other three heaters were cycled to failure and all failed open-circuit. The open-circuit failures were confirmed by post-test resistance measurements. The presumed failure locations are at the center coil location due to center conductor grain growth. 


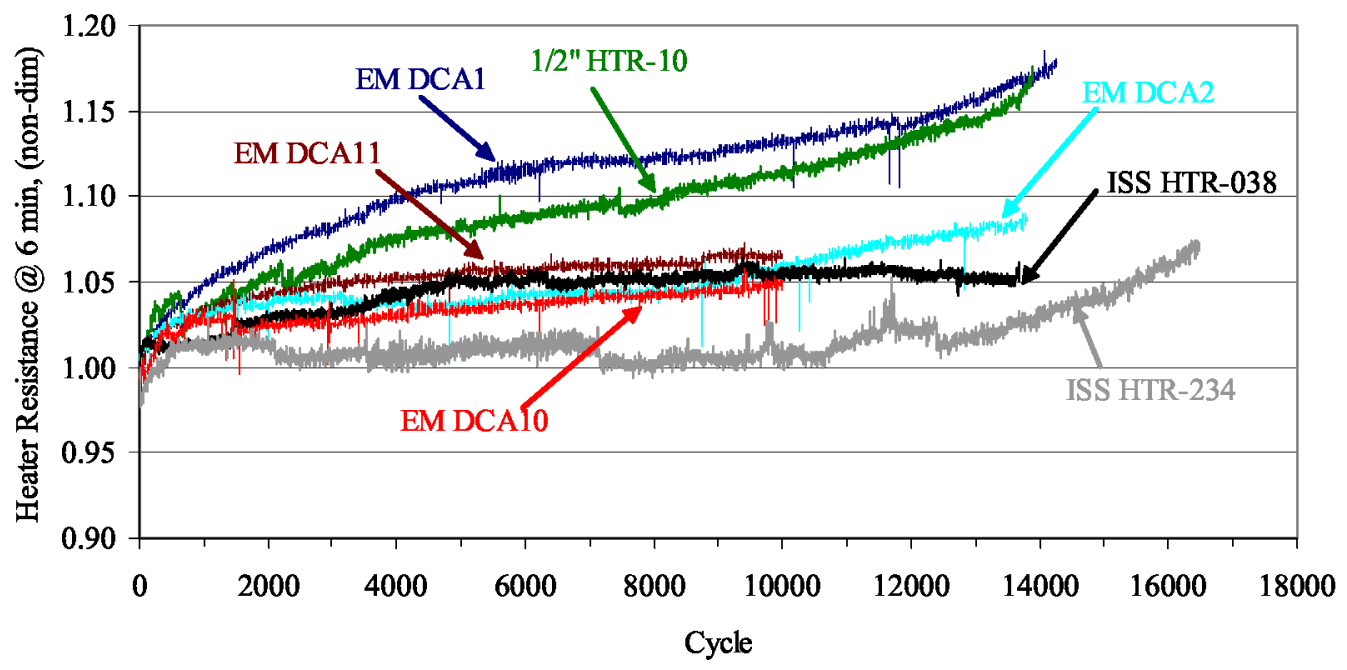

Figure 6.-Heater "hot" resistance normalized to BOL values versus time.

Destructive post-test analyses are beyond the scope of this paper. The numbers of individual heater cycles to failure are listed in Table 1. Prior to heater failure, a voltage-runoff characteristic is typically observed where the end-of-cycle voltage begins to increase with cycle number at a greater rate than over the majority of the cyclic test. Note that neither of the suspended heaters, EM DCA10 or EM DCA11, exhibited this type of behavior prior to suspension of the cyclic test.

A Weibull analysis of the three failed $1 / 2$ in. heaters was performed using a rank regression to determine the values for the two-parameter Weibull distribution. The Weibull distribution is defined in Equation (1). The values for $\beta$ and $\eta$ are determined to be 51.19 and 14,105 with a correlation coefficient of 0.93 , respectively. The determined Weibull distribution is plotted with the three failed $1 / 2$ in. heaters in Figure 7. The Weibull distribution is used to calculate the $1 / 2 \mathrm{in}$. GRC-manufactured heaters survival probability, with 90 percent confidence, shown in Figure 8. Included in the $1 / 2 \mathrm{in}$. heater survivability plot are the $B_{1}$ and $B_{10}$ cycle lifetimes of 11,457 and 12,615 cycles, respectively. These values exceed the target requirement and are considerably larger than the corresponding ISS plasma contactor values of 3,921 and 6,679 , respectively. Two factors contribute to the calculated increase in statistical life: all $1 / 2$ in. heaters lasted $\sim 2,000$ cycles more than the longest life ISS heater and the $1 / 2$ in. heater failures all failed within 500 cycles of each other compared to the ISS spread of $\sim 2,000$ cycles. The combination of these two factors cause the significant increase in GRC-manufactured $1 / 2$ in. heater statistical life. It should be noted that the $1 / 4$ in. ISS heaters, including HTR-038, were cycled in a power-limited manner compared to the $1 / 2$ in. heaters that were cycled in a current-limited fashion. The latter would be the harsher test as heater voltage, and therefore heater power, would continually increase over the testing duration.

$$
F(t)=1-e^{-\left(\frac{t-t_{0}}{\eta}\right)^{\beta}}
$$

A cause for the extended $1 / 2$ in. heater cyclic life may be due to a decreased operating temperature compared to the $1 / 4$ in. heaters. Thermocouple data from the $1 / 2$ in. HTR-10 and $1 / 4$ in. HTR-234 articles at end of the "on" cycle are shown as a function cycle number in Figure 9. In both cases the heaters were friction fit to cathode tubes with radiation shielding spot-welded on the outside of the heater coils, i.e., same setup as ISS heater qualification testing. No inserts were installed in the cathode tubes nor were keeper electrodes installed. The temperature data indicate the $1 / 2$ in. heater operates $\sim 200{ }^{\circ} \mathrm{C}$ cooler than the $1 / 4$ in. heater. Since grain growth leading to center conductor fracture is the expected failure mode and time at temperature is the dominant parameter for this behavior, it is expected that a heater that operates at a reduced temperature would last longer. 


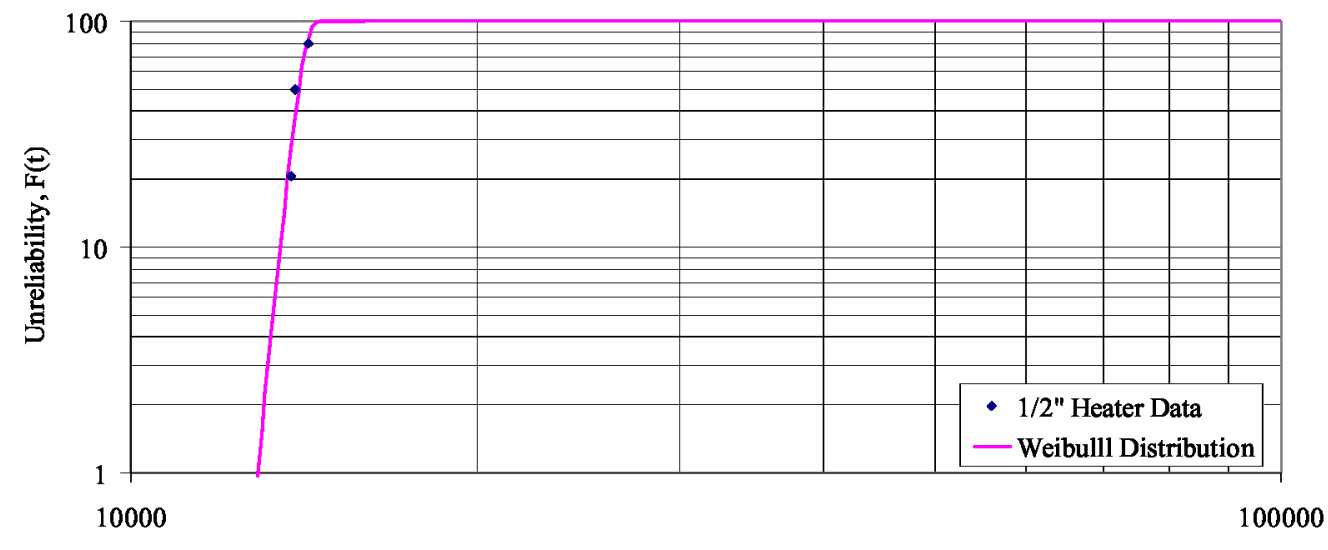

Number of Cycles to Failure

Figure 7.-Half inch GRC-manufactured heater Weibull probability plot.

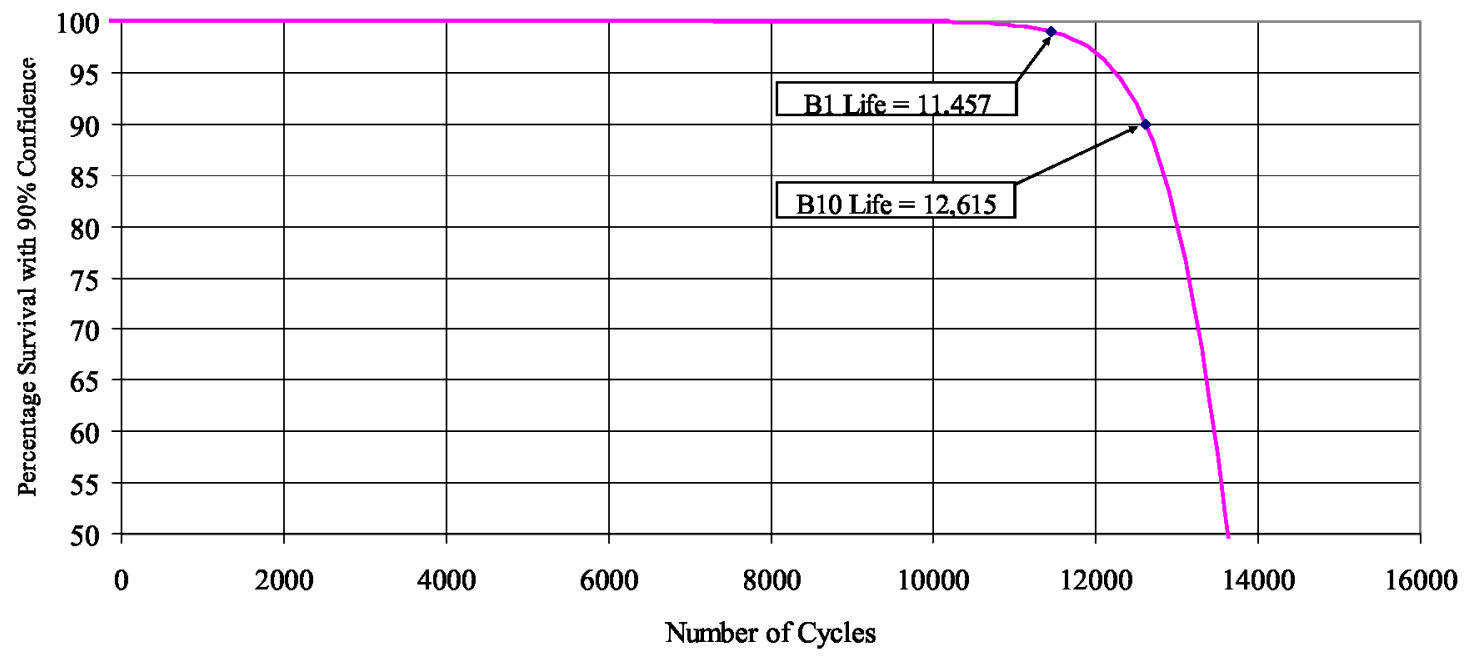

Figure 8.-Half inch GRC-manufactured heater Weibull analysis results.

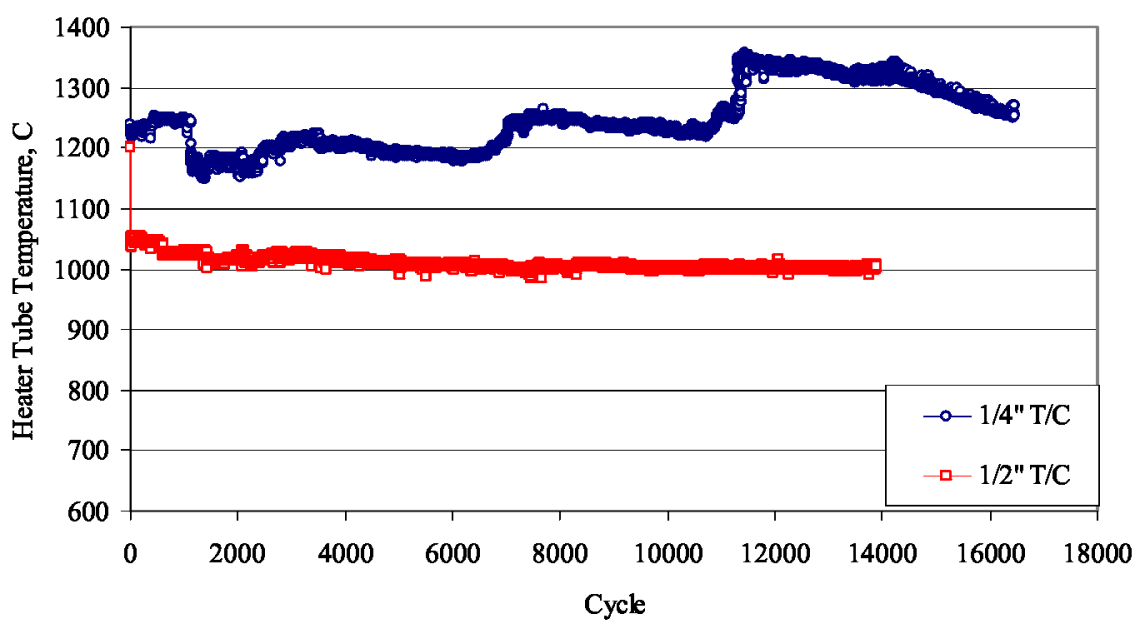

Figure 9.-Half inch heater coil, HTR-10, and $1 / 4$ in. heater coil, HTR-234 cathode tube temperatures in the plane of the orifice plate upstream surface. No inserts in cathode tubes or keepers, but radiation shield installed. 


\section{Conclusion}

A critical part of the NEXT thruster validation and qualification program is component lifetime testing. In addition to the thruster life test underway, several component life tests are completed, underway, or planned. The status of the high-voltage propellant isolator testing is presented. To date the propellant isolators have demonstrated $18,300 \mathrm{~h}$ of operation at an elevated temperature $65^{\circ} \mathrm{C}$ higher than the worst case expected flight temperature and representative pressure. The leakage current across the isolators has increased insignificantly and is currently five orders of magnitude lower than the maximum requirement. There is no threat to long-term high-voltage propellant isolator operation. The $1 / 2 \mathrm{in}$. heater cyclic testing results of five GRC-manufactured test articles are presented. A comprehensive GRCmanufactured $1 / 2$ in. heater qualification program has begun with the initial cyclic tests instilling confidence in the heater design and verification of manufacturing processes. Two heaters were cycled to $10,000 \mathrm{~h}$ and these two tests were suspended to preserve hardware. Neither demonstrated the voltage runoff observed prior to heater failure. Three of the heaters were cycled to failure with a minimum life of 13,789 cycles prior to failure. A Weibull analysis was performed on the three failed heaters, all of which failed open-circuit. The GRC-manufactured $1 / 2$ in. heaters have a $B_{10}$ lifetime, 12,615 cycles, which is considerably greater than the $1 / 4$ in. GRC-manufactured heaters, 6,679 cycles (the target requirement). The greater cyclic life may be in part due to lower operating temperature for the $1 / 2 \mathrm{in}$. heater inside the DCA. The increase in the $1 / 2$ in. heaters end-of-cycle "hot" resistances with number of cycles is consistent with ISS plasma contactor behavior.

\section{References}

1. Rayman, M.D., "The Successful Conclusion of the Deep Space 1 Mission: Important Results Without a Flashy Title," Space Technology, vol. 23, pp. 185-196, 2003.

2. Lee, M., et al., "Deep Space 1 Mission and Observation of Comet Borrelly," Deep Space 1 Mission and Observation of Comet Borrelly, $45^{\text {th }}$ IEEE International Midwest Symposium on Circuits and Systems, Tulsa, OK, Aug. 4, 2002.

3. Polk, J.E., et al., "Performance of the NSTAR Ion Propulsion System on the Deep Space One Mission," AIAA-2001-0965, 39 ${ }^{\text {th }}$ AIAA Aerospace Sciences Meeting and Exhibit Joint Propulsion Conference, Reno, NV, Jan. 8-11, 2001.

4. Oh, D., et al., "Deep Space Mission Applications for NEXT: NASA's Evolutionary Xenon Thruster," AIAA-2004-3806, 40 ${ }^{\text {th }}$ AIAA/ASME/SAE/ASEE Joint Propulsion Conference and Exhibit, Fort Lauderdale, FL, Jul. 11-14, 2004.

5. Oleson, S., et al., "Mission Advantages of NEXT: NASA's Evolutionary Xenon Thruster," AIAA2002-3969, 38 ${ }^{\text {th }}$ AIAA/ASME/SAE/ASEE Joint Propulsion Conference and Exhibit, Indianapolis, IN, Jul. 7-10, 2002.

6. Cupples, M., et al., "Application of Solar Electric Propulsion to a Comet Surface Sample Return Mission," AIAA-2004-3804, 40 ${ }^{\text {th }}$ AIAA/ASME/SAE/ASEE Joint Propulsion Conference and Exhibit, Fort Lauderdale, FL, Jul. 11-14, 2004.

7. Benson, S.W., et al., "NEXT Ion Propulsion System Configurations and Performance for Saturn System Exploration," AIAA-2007-5230, 43 ${ }^{\text {rd }}$ AIAA/ASME/SAE/ASEE Joint Propulsion Conference and Exhibit, Cincinnati, OH, Jul. 8-11, 2007.

8. Herman, D.A., et al., "Performance Evaluation of the Prototype-Model NEXT Ion Thruster," AIAA2007-5212, $43^{\text {rd }}$ AIAA/ASME/SAE/ASEE Joint Propulsion Conference and Exhibit, Cincinnati, OH, Jul. 8-11, 2007.

9. Pinero, L.R., et al., "Integration and Qualification of the NEXT Power Processing Unit," AIAA2007-5214, $43^{\text {rd }}$ AIAA/ASME/SAE/ASEE Joint Propulsion Conference and Exhibit, Cincinnati, OH, Jul. 8-11, 2007. 
10. Patterson, M.J. and Benson, S.W., "NEXT Ion Propulsion System Development Status and Capabilities," Conference Proceedings and NASA/TM - 2008-214988, 2007 NASA Science Technology Conference, College Park, MD, Jun. 19-21, 2007.

11. Snyder, J.S., et al., "Vibration Test of a Breadboard Gimbal for the NEXT Ion Engine," AIAA-20064665, $42^{\text {nd }}$ AIAA/ASME/SAE/ASEE Joint Propulsion Conference and Exhibit, Sacramento, CA, Jul. 9-12, 2006.

12. Aadland, R.S., et al., "Development Status of the NEXT Propellant Management System," AIAA2004-3974, 40 ${ }^{\text {th }}$ AIAA/ASME/SAE/ASEE Joint Propulsion Conference and Exhibit, Fort Lauderdale, FL, Jul. 11-14, 2004.

13. Hoskins, W.A., et al., "Development of a Prototype Model Ion Thruster for the NEXT System," AIAA-2004 4111, 40 ${ }^{\text {th }}$ AIAA/ASME/SAE/ASEE Joint Propulsion Conference and Exhibit, Fort Lauderdale, FL, Jul. 11-14, 2004.

14. Monheiser, J., et al., "Development of a Ground Based Digital Control Interface Unit (DCIU) for the NEXT Propulsion System," AIAA-2004 4112, 40 ${ }^{\text {th }}$ AIAA/ASME/SAE/ASEE Joint Propulsion Conference and Exhibit, Fort Lauderdale, FL, Jul. 11-14, 2004.

15. Van Noord, J.L. and Williams, G.J., "Lifetime Assessment of the NEXT Ion Thruster," AIAA-20075274, $43^{\text {rd }}$ AIAA/ASME/SAE/ASEE Joint Propulsion Conference and Exhibit, Cincinnati, OH, Jul. 8-11, 2007.

16. Herman, D.A., et al., "NEXT Long-Duration Test Plume and Wear Characteristics after 16,550 h of Operation and $337 \mathrm{~kg}$ of Xenon Processed," AIAA-2008-4919, 44th AIAA/ASME/SAE/ASEE Joint Propulsion Conference and Exhibit, Hartford, CT, Jul. 21-23, 2008.

17. Mantenieks, M.A., "Status of 30-Centimeter-Diameter Mercury Ion Thruster Isolator Development," NASA TM X-73514, Nov. 1976.

18. Sovey, J.S., et al., "NSTAR High Voltage Propellant Isolator Test," NASA/TM-2004-212921, Feb. 2004.

19. Hart, S.L., et al., "Investigation and Development of a High Voltage Propellant Isolator for Ion Thrusters," IEPC-2005-316, $29^{\text {th }}$ International Electric Propulsion Conference, Princeton, NJ, Oct. 2005.

20. Patterson, M.J., et al., "Space Station Cathode Design, Performance, and Operating Specifications," IEPC-1997-170, 25 ${ }^{\text {th }}$ International Electric Propulsion Conference, Cleveland, OH, Aug. 24-28, 1997.

21. Sengupta, A., et al., "Status of the Extended Life Test of the Deep Space 1 Flight Spare Ion Engine after 30,352 Hours of Operation," AIAA-2003-4558, 39 ${ }^{\text {th }}$ AIAA/ASME/SAE/ASEE Joint Propulsion Conference and Exhibit, Huntsville, AL, Jul. 20-23, 2003.

22. Pinero, L.R. and Sovey, J.S., "NEXT Thruster Component Verification Testing," AIAA-2007-5276, $43^{\text {rd }}$ AIAA/ASME/SAE/ASEE Joint Propulsion Conference and Exhibit, Cincinnati, OH, Jul. 8-11, 2007.

23. Van Noord, J.L., "NEXT Ion Thruster Thermal Model," AIAA-2007-5218, 43 ${ }^{\text {rd }}$ AIAA/ASME/SAE/ ASEE Joint Propulsion Conference and Exhibit, Cincinnati, OH, Jul. 8-11, 2007.

24. Van Noord, J.L. and Herman, D.A., "Application of the NEXT Ion Thruster Lifetime Assessment to Thruster Throttling," AIAA-2008-4526, 44 ${ }^{\text {th }}$ AIAA/ASME/SAE/ASEE Joint Propulsion Conference and Exhibit, Hartford, CT, Jul. 21-23, 2008.

25. Soulas, G.C., et al., "NEXT Ion Engine 2000 Hour Wear Test Results," AIAA-2004-3791, 40 AIAA/ASME/SAE/ASEE Joint Propulsion Conference and Exhibit, Fort Lauderdale, FL, Jul. 11-14, 2004.

26. Britton, M., et al., "Destructive Analysis of the NEXT 2000-Hour Wear Test Hollow Cathode Assemblies," NASA/TM-2005-213387, NASA Glenn Research Center, Cleveland, OH, Jul. 2005.

27. Williams, G.J., et al., "Results of the $2000 \mathrm{hr}$ Wear Test of the HiPEP Ion Thruster with Pyrolitic Graphite Ion Optics," AIAA-2006 4668, 42 ${ }^{\text {nd }}$ AIAA/ASME/SAE/ASEE Joint Propulsion Conference and Exhibit, Sacramento, CA, Jul. 9-12, 2006. 


\begin{tabular}{|c|c|c|}
\hline \multicolumn{2}{|c|}{ REPORT DOCUMENTATION PAGE } & $\begin{array}{c}\text { Form Approved } \\
\text { OMB No. 0704-0188 }\end{array}$ \\
\hline \multicolumn{3}{|c|}{ 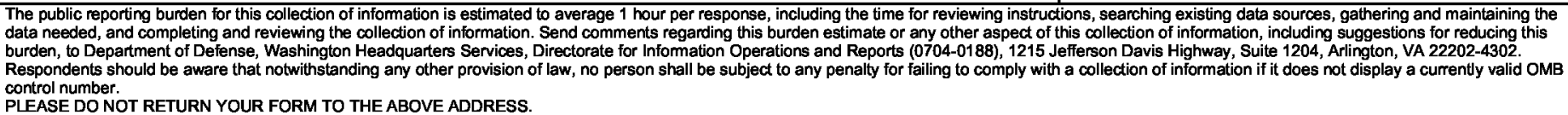 } \\
\hline $\begin{array}{l}\text { 1. REPORT DATE (DD-MM-YYYY) } \\
01-05-2009\end{array}$ & $\begin{array}{l}\text { 2. REPORT TYPE } \\
\text { Technical Memorandum }\end{array}$ & 3. DATES COVERED (From - To) \\
\hline \multirow{3}{*}{\multicolumn{2}{|c|}{$\begin{array}{l}\text { 4. TITLE AND SUBTITLE } \\
\text { NASA's Evolutionary Xenon Thruster (NEXT) Component Verification Testing }\end{array}$}} & 5a. CONTRACT NUMBER \\
\hline & & 5b. GRANT NUMBER \\
\hline & & 5c. PROGRAM ELEMENT NUMBER \\
\hline \multirow{3}{*}{\multicolumn{2}{|c|}{$\begin{array}{l}\text { 6. AUTHOR(S) } \\
\text { Herman, Daniel, A.; Pinero, Luis, R.; Sovey, James, S. }\end{array}$}} & 5d. PROJECT NUMBER \\
\hline & & 5e. TASK NUMBER \\
\hline & & $\begin{array}{l}\text { 5f. WORK UNIT NUMBER } \\
\text { WBS } 346620.04 .05 .03 .13\end{array}$ \\
\hline \multicolumn{2}{|c|}{$\begin{array}{l}\text { 7. PERFORMING ORGANIZATION NAME(S) AND ADDRESS(ES) } \\
\text { National Aeronautics and Space Administration } \\
\text { John H. Glenn Research Center at Lewis Field } \\
\text { Cleveland, Ohio 44135-3191 }\end{array}$} & $\begin{array}{l}\text { 8. PERFORMING ORGANIZATION } \\
\text { REPORT NUMBER } \\
\text { E-16928 }\end{array}$ \\
\hline \multirow{2}{*}{\multicolumn{2}{|c|}{$\begin{array}{l}\text { 9. SPONSORING/MONITORING AGENCY NAME(S) AND ADDRESS(ES) } \\
\text { National Aeronautics and Space Administration } \\
\text { Washington, DC 20546-0001 }\end{array}$}} & $\begin{array}{l}\text { 10. SPONSORING/MONITOR'S } \\
\text { ACRONYM(S) } \\
\text { NASA }\end{array}$ \\
\hline & & $\begin{array}{l}\text { 11. SPONSORING/MONITORING } \\
\text { REPORT NUMBER } \\
\text { NASA/TM-2009-215612; AIAA-2008- } \\
4812\end{array}$ \\
\hline \multicolumn{3}{|c|}{$\begin{array}{l}\text { 12. DISTRIBUTION/AVAILABILITY STATEMENT } \\
\text { Unclassified-Unlimited } \\
\text { Subject Category: } 20 \\
\text { Available electronically at http://gltrs.grc.nasa.gov } \\
\text { This publication is available from the NASA Center for AeroSpace Information, 301-621-0390 }\end{array}$} \\
\hline
\end{tabular}

\section{SUPPLEMENTARY NOTES}

\section{ABSTRACT}

Component testing is a critical facet of the comprehensive thruster life validation strategy devised by the NASA's Evolutionary Xenon Thruster (NEXT) program. Component testing to-date has consisted of long-duration high voltage propellant isolator and high-cycle heater life validation testing. The high voltage propellant isolator, a heritage design, will be operated under different environmental condition in the NEXT ion thruster requiring verification testing. The life test of two NEXT isolators was initiated with comparable voltage and pressure conditions with a higher temperature than measured for the NEXT prototype-model thruster. To date the NEXT isolators have accumulated $18,300 \mathrm{~h}$ of operation. Measurements indicate a negligible increase in leakage current over the testing duration to date. NEXT $1 / 2$ in. heaters, whose manufacturing and control processes have heritage, were selected for verification testing based upon the change in physical dimensions resulting in a higher operating voltage as well as potential differences in thermal environment. The heater fabrication processes, developed for the International Space Station (ISS) plasma contactor hollow cathode assembly, were utilized with modification of heater dimensions to accommodate a larger cathode. Cyclic testing of five $1 / 2 \mathrm{in}$. diameter heaters was initiated to validate these modified fabrication processes while retaining high reliability heaters. To date two of the heaters have been cycled to 10,000 cycles and suspended to preserve hardware. Three of the heaters have been cycled to failure giving a B10 life of 12,615 cycles, approximately 6,000 more cycles than the established qualification B10 life of the ISS plasma contactor heaters.

15. SUBJECT TERMS

Ion engines; Ion optics; Ion propulsion; Electric propulsion; Electrostatic propulsion; Plasma propulsion

\begin{tabular}{|c|c|c|c|c|c|}
\hline \multicolumn{3}{|c|}{ 16. SECURITY CLASSIFICATION OF: } & \multirow{2}{*}{$\begin{array}{l}\text { 17. LIMITATION OF } \\
\text { ABSTRACT }\end{array}$} & \multirow{2}{*}{$\begin{array}{l}\text { 18. NUMBER } \\
\text { OF } \\
\text { PAGES } \\
18\end{array}$} & \multirow{2}{*}{$\begin{array}{l}\text { 19a. NAME OF RESPONSIBLE PERSON } \\
\text { STT Help Desk (email:help@sti.nasa.gov) } \\
\text { 19b. TELEPHONE NUMBER (include area code) } \\
\text { 301-621-0390 }\end{array}$} \\
\hline $\begin{array}{l}\text { a. REPORT } \\
\text { U }\end{array}$ & $\begin{array}{l}\text { b. ABSTRACT } \\
\text { U }\end{array}$ & $\begin{array}{l}\text { c. THIS } \\
\text { PAGE } \\
\text { U }\end{array}$ & & & \\
\hline
\end{tabular}



